\title{
Presentation of Combinatorial Concepts in Mathematics Textbooks and Its Compliance with a Concept Development Theory
}

\author{
Soulad zavedení kombinatorických konceptů v učebnicích matematiky s teorií \\ poznávacího procesu
}

\author{
David Zenkl ${ }^{1, *}$ \\ ${ }^{1}$ Pedagogická fakulta, Univerzita Karlova, Magdalény Rettigové 4, 116 39, Praha 1, Czech Republic; \\ david.zenkl@student.pedf.cuni.cz
}

\begin{abstract}
This article analyses the approach taken by five Czech secondary school mathematics textbooks to selected combinatorial concepts, in order to determine the extent to which they provide pedagogical support to teachers based on the theory of generic models, which is a theory of concept development. The analysis of textbooks in relation to this theory focused on the presence and quality of a) isolated models and non-models of future knowledge, b) prompts to generalise as a prerequisite for the creation of a generic model, and c) the supportive role of graphical representations in developing combinatorial thinking. Most notably, we identified insufficient motivation for combinatorial problems, few isolated models of future knowledge, the absence of explicit prompts to generalise and a consequent lack of a significant concept of isomorphism. Despite the research-proven positive influence of the creation of graphical representations on the development of pupils' combinatorial thinking, they are rare in textbook chapters about combinatorics, and lack diversity. With a few exceptions, textbook authors do not encourage readers to create their own graphical representations. One textbook stood out in that it frequently prompts the creation of personalised representations, works purposefully with isomorphic problems and encourages the reader to generalise specific procedures.
\end{abstract}

Článek analyzuje přistupy k vybraným kombinatorickým konceptům v pěti českých středoškolských učebnicích matematiky s cílem zjistit, do jaké míry tyto učebnice poskytují podporu učitelům pro výuku založenou na teorii poznávacího procesu v matematice. Analýza učebnic byla vedena na pozadí teorie generických modelů, přičemž důraz byl položen na přítomnost a kvalitu a) izolovaných modelů a nemodelů budoucího poznatku, b) výzev k zobecňování jako nutnému předpokladu tvorby generického modelu, c) grafických reprezentací jako nezbytné podpory rozvoje kombinatorického uvažování. Bylo zjištěno, že učebnice jsou si v mnoha směrech dosti podobné, ale $\mathrm{v}$ jistých ohledech se odlišují. V učebnicích jsme identifikovali mj. nedostatečnou motivaci pro kombinatoriku, nízký počet izolovaných modelů budoucího poznatku, absenci explicitních výzev k zobecňování a z toho plynoucí absenci významného konceptu izomorfismus. Navzdory výzkumně prokázanému pozitivnímu vlivu př́tomnosti a vlastní tvorby grafických reprezentací na rozvoj žákovského kombinatorického myšlení se $\mathrm{v}$ učebnicích vyskytují reprezentace zřídka, a navíc s malou rozmanitostí. Autoři učebnic až na výjimky nevyzývají čtenáře k tvorbě vlastních grafických reprezentací. Od analyzovaných učebnic se odlišuje jedna, která obsahuje časté výzvy $\mathrm{k}$ tvorbě vlastních reprezentací, pracuje záměrně s izomorfními úlohami a vyzývá čtenáře k zobecňování konkrétních postupů.
Key words: combinatorics, textbook graphical representation, concept development theory, Theory of Generic Models.

Received 3/2021

Revised 6/2021

Accepted 6/2021

\section{Klíčová slova:} kombinatorika, učebnice, grafická reprezentace, teorie pojmotvorného procesu, teorie generických modelů.

Zasláno 3/2021

Revidováno 6/2021

Přijato 6/2021

\section{Introduction}

Mathematics can be taught in various ways, but teachers, textbook authors, and researchers in mathematics education agree that the goal is for pupils to have a good understanding of mathematics. Following Hejný and Kuřina (2009), we understand the educational process to consist of individual pupils constructing their own knowledge. Instruction designed according to how mathematics knowledge is built in pupils' minds is a prerequisite for understanding (Vinner, 2014). Our study is based on the assumption that textbooks can help the teacher to prepare instruction that is aligned with pupils' conceptual development. Indeed, textbooks have been shown to be one of the most important determinants in the teaching of mathematics (Fan, 2013). At the same time, it has been shown that the effect of textbooks on learning mathematics is mediated through their use in lessons by teachers (e.g., Tarr et al., 2006; Van Steenbrugge et al., 2013), leading to the question of whether textbooks provide appropriate support for teachers.

We pursue this question on the topic of combinatorics - a part of discrete mathematics that consists of calculating the selection and arrangement of objects in a finite set. Combinatorics has received attention since the early days of mathematics education research (e.g., Fischbein \& Gazit, 1988; Hejný et al., 
1990; Kapur, 1970). Combinatorial problems can be used to develop pupils' ability to make conjectures and generalise, and thus go beyond the field of mathematics. For example, it has been shown that the incorporation of combinatorial and logical problems into mathematics lessons enabled pupils to transfer their experience hereby to biology, physics and chemistry lessons (Stofflett \& Baker, 2016). According to Grimaldi (2003), the ability to divide a problem into subproblems, which provides key insights into combinatorial reasoning, is similar to the ability to split a computer algorithm into several components, which are then "more easily workable programming tasks" (p. 41). Moreover, combinatorial reasoning helps pupils to grasp many related concepts including isomorphism, relations, or equivalence classes (Kapur, 1970). In short, combinatorics represent an important part of mathematics which merits investigation.

Based on the above, our study aims to determine how selected combinatorial concepts and procedures are presented in mathematics textbooks, and whether the textbooks support teachers in their effort to design instruction that is aligned with how pupils acquire combinatorial concepts. The theoretical background of our study is the theory of generic models (Hejný, 2012), one of concept development theories that have been created to describe how pupils acquire knowledge in mathematics. According to this theory, the appropriate motivation is an important pre-requisite of learning in mathematics and this learning starts with a series of isolated models of future knowledge. Thus, we will investigate how the content is motivated in the textbooks, and whether they provide a variety of isolated models of combinatorial concepts which could help pupils to develop a generic model as a precursor to gaining abstract knowledge with understanding.

Combinatorics provides a space for meaningful problems that can be solved in many ways with various representational tools, including manipulation (English, 2005). It has been shown that visual representations are essential to solving combinatorial problems (e.g., Lockwood \& Gibson, 2016). Thus, our second focus is on the way the textbooks we analyse include and promote visual representations to solve combinatorial problems.

\section{Combinatorial concepts and procedures selected for the study}

In this section, we describe the concepts and procedures which are essential for the development of combinatorial thinking and which will be our focus in our analysis of selected textbooks.

The two following rules are at the heart of combinatorial considerations (e.g., Vondrová, 2019).

The Rule of Sum:

If a first task can be performed in $m$ ways, while a second task can be performed in $n$ ways, and the two tasks cannot be performed simultaneously, then performing either task can be accomplished in any one of $m+n$ ways. (Grimaldi, 2003, p. 3)

The Rule of Product:

If a procedure can be broken down into first and second stages, and if there are $m$ possible outcomes for the first stage and if, for each of these outcomes, there are $n$ possible outcomes for the second stage, then the total procedure can be carried out, in the designated order, in $m n$ ways. (Grimaldi, 2003, p. 4)

Two of the main combinatorial configurations, namely, $k$-permutations and combinations, will be targeted. Any linear organisation of a collection of $k$ objects out of $n$ distinct objects with reference to order is called an $k$-permutation. A selection of $k$ objects out of $n$ distinct objects with no reference to order is called a combination (Grimaldi, 2003, pp. 7, 15). Table 1 shows the properties of these configurations without repetition. The formulas concern the number of collections and how to select or order $k$ of $n$ distinct objects.

Tab. 1: $k$-permutations and combinations without repetition

\begin{tabular}{lcc}
\hline Order is relevant & Type of result & Formula \\
\hline Yes & $k$-permutations & $V(n, k)=n(n-1)(n-2) \cdot \ldots \cdot(n-k+1)=\frac{n !}{(n-k) !}$ \\
\hline No & Combinations & $C(n, k)=\frac{n !}{k !(n-k) !}=\left(\begin{array}{l}n \\
k\end{array}\right)^{*}$ \\
\hline
\end{tabular}

* $\left(\begin{array}{l}n \\ k\end{array}\right)$ is called a combination number.

Visual representations are essential in the teaching of combinatorics (Arcavi, 2003; English, 2005; Lockwood \& Gibson, 2016; Salavatinejad et al., 2021; Uptegrove, 2015; Vondrová, 2019; Zahner \& Corter, 
$\begin{array}{llllll}1 & 5 & 10 & 10 & 5 & 1\end{array}$

Fig. 1: Six rows of Pascal's triangle

2010). One such visual representation is Pascal's triangle, in which the combination numbers are arranged in the shape of a triangle (Fig. 1).

The numbers in the rows can be generated recursively according to Pascal's identity

$$
\left(\begin{array}{l}
n \\
k
\end{array}\right)+\left(\begin{array}{c}
n \\
k+1
\end{array}\right)=\left(\begin{array}{l}
n+1 \\
k+1
\end{array}\right)
$$

valid for $n, k \in \mathbb{N}_{0} ; n \geq k$.

\section{Theoretical framework and literature review}

Many factors influence how pupils learn. According to Apple (1986, cited in Fan et al., 2013), it is the textbook that mainly supports material conditions for teaching and learning and influences how mathematics is taught by teachers and experienced by pupils. Teachers perceive that their choice of a textbook has an impact on pupils' performance (Van Steenbrugge et al., 2013), which also seems to be supported by research.

District-adopted textbook strongly influences both what and how mathematics is taught to middle school mathematics students. Coupled with the high frequency of textbook use by teachers, these data suggest that textbooks likely impact students' mathematics experience in important ways. (Tarr et al., 2006, p. 200)

Textbook analysis plays an important role in our understanding of teachers' lesson design, provided that researchers go beyond descriptive analysis and comparison (Fan, 2013). Our study is not of a causal or relational nature; rather, it aims to augment the descriptive analysis by considering whether secondary school mathematics textbooks provide teachers with sound support when designing instruction that is aligned with how pupils learn mathematics. To this end, we use a concept development theory which is widely used in the Czech mathematics education context.

\subsection{Theory of generic models as a concept development theory}

Since the early days of mathematics education research, researchers have striven to capture how pupils acquire new knowledge in mathematics (Vinner, 2014) and to apply this knowledge to the design of instruction aimed at understanding. In this study, we use the Theory of Generic Models (here TGM), which is a process-object theory ${ }^{1}$. TGM was developed in the Slovak and Czech contexts and presents a theoretical model of how pupils appropriate new mathematics knowledge.

Our model of the process of gaining knowledge is based on five stages. It starts with motivation and has at its core two mental shifts: the first leads from concrete knowledge (isolated models) to generalised knowledge (generic knowledge) and the second from generic to abstract knowledge. The permanent part of this process of gaining knowledge is that of crystallisation, which involves integrating new knowledge into the already existing mathematical structure [...] (Hejný, 2012, pp. 44-45)

Hejný $(2012,2014)$ presents TGM in more detail. Here, we will concentrate on how its elements can be incorporated into the presentation of content in mathematics textbooks.

\footnotetext{
${ }^{1}$ These theories are based on an ongoing feature of learning and doing mathematics, namely processes become objects to be acted upon by further processes. In this process, the actions do not lose their action quality but rather a dual perception originates (Mason \& Johnston-Wilder, 2005)
} 
Motivation in textbooks can take the form of motivational texts, historical or real-life or otherwise attractive contexts, questions and problems stimulating pupils' curiosity, etc. It should lead to pupils' active work with the content. An isolated model (IM) is a specific instance of future knowledge. IMs in textbooks take the form of problems and questions for pupils to solve or answer, which precede the introduction of abstract knowledge in the form of a mathematical definition or theorem. Hejný (2004) emphasises that for a good understanding of the subject matter, it is not sufficient to present pupils with examples (IMs) but also with non-examples (non-models) of future knowledge. The quantity and quality of IMs impact the opportunities afforded to pupils for dealing with content. Thus, it makes sense to investigate IMs provided by textbooks.

The process of generalisation leads to the stage of generic models (GMs).

The generic model is created from the community of its isolated models and has two basic relationships to this community:

1. it denotes both the core of this community and the core of relationships between individual models, and

2. it is an example or representative of all its isolated models. (Hejný, 2012, p. 45)

"Finding a common core in seemingly different situations, in other words, seeing what is the same in given situations" means realising that "they are in a certain sense isomorphic" (Hejný, 2014, p. 151). This stage is of crucial importance in combinatorics (English, 2005).

However, the process of generalisation cannot be directly observed as it takes place in pupils' heads. The generic model cannot be passed on to pupils; the teacher can only assist pupils by providing them with enough IMs and with enough opportunities to deal with them (Vondrová, 2019). Thus, in textbooks, this stage of learning is only encouraged in the form of indirect support, such as a task to look for common features of the IMs or a call to generalise from specific instances. Reaching a stage of GM for combinatorial problems mainly means that the pupil can identify a common structure of problems, that is, to recognise that the problems may vary in terms of context but are essentially isomorphic in their mathematical structure.

The process of abstraction leads to the stage of abstract knowledge. This differs from the stage of GMs by a change in language which the pupil is able to use while solving the problem (Hejný, 2014). In textbooks, it takes the form of mathematical definitions, theorems, or formulas, including symbolism, namely, algebraic language (see the formulas in Table 1).

\subsection{Visual representations}

It has been acknowledged that pupils' learning in mathematics benefits from visual representations (e.g., Arcavi, 2003). The development of combinatorial thinking is based on searching for an organisational principle (Hejný et al., 1990; Vondrová, 2019; Zahner \& Corter, 2010), which helps pupils to find all $k$-permutations or combinations while avoiding counting some of them more than once. A suitable visual representation may significantly enhance the pupil's chances of finding such an organisational principle and/or its successful enactment in the calculation (e.g., Lockwood \& Gibson, 2016). A better understanding of combinatorial problems is mediated by visual representation, which reduces the problems' complexity (Salavatinejad et al., 2021).

On the topic of combinatorics, Salavatinejad et al. (2021) distinguished the following categories of pupils' visual representations: trees, Venn diagrams, systematic lists, charts (other than tree graphs), tables, and figures. There are other types of visual representations, including Pascal's triangle, and positional or compartmental schemas. Zahner and Corter (2010) use similar categories for probability problems: pictures, spatial reorganisation of the given information, outcome listings, contingency tables (see Fig. 2), Venn diagrams, trees, and novel graphical representations.

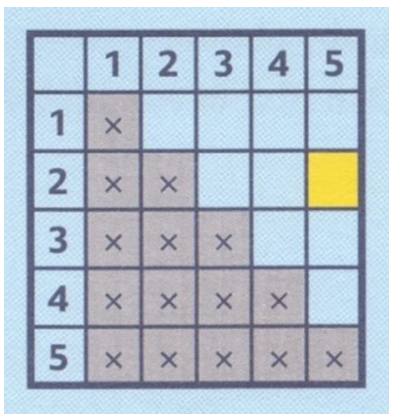

Fig. 2: A contingency table as a visual representation (Hejný \& Šlom, 2017, p. 55) 
Some research attention has been devoted to learner-generated visual representations when solving combinatorial problems (Hejný et al., 1990; Speiser et al., 2007; Uptegrove, 2015; Zahner \& Corter, 2010). They are used to support both finding a mathematical model for the problem and recording the solution's progress and the result.

How secondary school pupils use representations of trees, tables, or arrays when solving problems in combinatorics has been documented (Fischbein \& Gazit, 1988; Hejný et al., 1990; Uptegrove, 2015). However, after being introduced to combinatorics, the pupils were found to use trees only rarely and to prefer formulas (Batanero et al., 1997).

English (2005) brings forward a recommendation that pupils need to develop representational fluency, that is, the ability to work flexibly with different representational forms in combinatorics. Indeed, some studies document a positive influence of visual representations on pupils' solutions to combinatorial problems (Uptegrove, 2015; Zahner \& Corter, 2010). For example, the use of systematic lists is positively correlated with the success of university students in solving problems (Lockwood \& Gibson, 2016).

To sum up, the use of visual representations is considered to be essential for the development of pupils' combinatorial thinking. Therefore, it seems pertinent to investigate how mathematics textbooks work with such representations.

\subsection{Research questions}

The study presented in this paper aims to answer the following research questions:

RQ1: To what extent does the structure and presentation of content in Czech mathematics textbooks comply with the theory of concept development in mathematics (TGM)?

RQ2: How are visual representations presented and promoted in these textbooks? Is there diversity among them?

\section{Methodology}

In this section, the methods used to analyse and compare textbooks are discussed. First, the textbooks are introduced against the curricular context. Second, the selection of textbooks and the procedures of their analysis and comparison are described.

\subsection{Curricular context}

Since 2004, curricular documents have been developed at national and school levels in the Czech Republic. $^{2}$ The national level, produced by the Ministry of Education, Youth and Sports (MŠMT), includes Framework Educational Programmes (FEPs), which set binding educational norms across various educational stages. The school level consists of school educational programmes, which form the basis of education at individual schools.

According to the FEP for primary schools, pupils aged 12 to 15 are led towards "developing combinatorial and logic thinking, to critical reasoning and clear and concise argumentation via solving mathematics problems" (MŠMT, 2017, p. 31) Throughout the document, there is no mention of the propaedeutics of combinatorics. ${ }^{3}$ The Czech curricular documents do not capitalise on the advantages that combinatorics bring in terms of pupils' learning of mathematics (see Section 1).

According to the FEP for secondary grammar schools (pupils aged 15 to 19), the only expected outcome in the field of combinatorics is that the pupil shall:

Solve real problems with a combinatorial implication (characterise possible cases, form models using combinatorial groups, and determine their number), utilise combinatorial methods when calculating probabilities, transform terms with factorials and binomial coefficients. (MŠMT, 2016, p. 24)

The specific subject matter prescribed by the FEP consists of elementary combinatorial problems, $k$-permutations, permutations, combinations (without repetition), the binomial theorem, and Pascal's triangle. As the schools prepare their school educational programmes, they may add other combinatorial concepts and decide on the depth at which they want to deal with combinatorics. Once the learning outcomes are put into the school educational programme, they become obligatory for the school.

Secondary school mathematical textbooks in the Czech Republic are usually written in series comprising separate books on particular mathematical topics. The publishers ask the MŠMT for official approval;

\footnotetext{
${ }^{2}$ https://eacea.ec.europa.eu/national-policies/eurydice/content/teaching-and-learning-single-structure-education-7_en

${ }^{3}$ The propaedeutics of combinatorics is strongly recommended by Kapur (1970) or Hejný et al. (1990).
} 
however, there are also textbooks on the market that have not been approved (and can be used at schools). It is common that teachers from the school decide on one textbook series they will use. However, individual teachers can also use other textbooks or no textbook at all (and give pupils their own compilation of material). Secondary school pupils have to purchase textbooks according to the recommendations of their teachers, unlike primary school pupils who are provided with the textbook by the school.

\subsection{Data sources}

First, we searched secondary school mathematics textbooks (aimed at pupils 15-19) written in Czech and currently available in the Czech Republic, and selected those containing combinatorics. In this way, we found four printed textbooks, none of which contain only combinatorics. All the textbooks have chapters on probability and statistics, too. The data was complemented by an electronic 'textbook' written by M. Krynický, ${ }^{4}$ as our experience from conferences for teachers and social media shows that many secondary school teachers use it. Unfortunately, no official information is available showing the number of schools where the textbooks are used.

Table 2 presents an overview of the textbooks. Each is denoted by a letter (D, F, G, K, P). Textbooks $\mathrm{F}$ and $\mathrm{P}$ have an electronic version, which is mostly the same as the printed one and thus, only the printed ones were analysed. Textbook D is accompanied by a workbook, which was not included in our analysis as the other textbooks do not have a workbook. Only one of our textbook sample is accompanied by a teacher's book. ${ }^{5}$ Krynický's texts are noteworthy as they include didactic notes in which the author summarises his teaching experience with the material and provides readers with pedagogical hints. The hints can serve a similar function to a teacher's book.

Tab. 2: Textbooks included in the study

\begin{tabular}{|c|c|c|c|c|c|}
\hline$\overline{\text { Publisher }}$ & Textbook title (transl.) & Code & Authors, year & $\begin{array}{l}\text { Printed/ } \\
\text { electronic }\end{array}$ & $\begin{array}{c}\text { Workbook/ } \\
\text { Teacher book }\end{array}$ \\
\hline $\begin{array}{l}\text { Didaktis, } \\
\text { spol. s r. o. }\end{array}$ & $\begin{array}{l}\text { Matematika pro střední školy } \\
\text { (Mathematics for secondary schools) }\end{array}$ & $\overline{\mathrm{D}}$ & $\begin{array}{l}\text { Horenský et al., } \\
2015\end{array}$ & yes/no & yes/yes \\
\hline$\overline{\text { Fraus }}$ & $\begin{array}{l}\text { Matematika s nadhledem } \\
\text { (Mathematics with a view) }\end{array}$ & $\mathrm{F}$ & Tlustý, 2020 & yes/yes & $\mathrm{no} / \mathrm{no}$ \\
\hline $\begin{array}{l}\text { Prometheus, } \\
\text { spol. s r.o. }\end{array}$ & $\begin{array}{l}\text { Matematika pro gymnázia } \\
\text { (Mathematics for grammar schools) }\end{array}$ & $\mathrm{G}$ & $\begin{array}{l}\text { Calda \& Dupač, } \\
2012\end{array}$ & yes/no & $\mathrm{no} / \mathrm{no}$ \\
\hline M. Krynický & $\begin{array}{l}\text { Matematika SS.realisticky.cz } \\
\text { (Mathematics SŠ.realisticky.cz) }\end{array}$ & $\bar{K}$ & $\begin{array}{l}\text { Krynický, 2021a, } \\
\text { 2021b }\end{array}$ & no/yes & no/yes \\
\hline $\begin{array}{l}\text { Prometheus, } \\
\text { spol. s r.o. }\end{array}$ & $\begin{array}{l}\text { Matematika pro střední školy } \\
\text { (Mathematics for secondary schools) }\end{array}$ & $\mathrm{P}$ & Robová et al., 2013 & yes/yes & no/no \\
\hline
\end{tabular}

\subsection{Data analysis}

For this study, we assumed that the authors planned the content to be presented to pupils in the textbook's order. Following Fan et al. (2013), we conducted a comparative textbook analysis in which each textbook was analysed separately, and then the results were compared.

First, we determined the space devoted to combinatorics within the whole series of textbooks.

Second, we considered the number of problems in the chapter on combinatorics. We restricted ourselves to problems set within a particular context and formulated in words and omitted problems in which manipulations on expressions were performed or equations and inequalities with factorials or combination numbers solved. Such problems were considered more important for algebra than for the development of combinatorial thinking.

Third, we analysed the following for each of the selected concepts and procedures (see Section 2):

- the presence and nature of motivation for combinatorial problems;

- the number and nature of problems that could be considered IMs of future knowledge;

- the elements of the text which could be viewed as prompts to generalise IMs into GM (in other words, a prompt bringing to pupils' attention that two or more problems are isomorphic, have the same inner structure);

- the place and nature of the presentation of knowledge in a symbolic language.

\footnotetext{
${ }^{4}$ This is, in fact, a collection of electronic texts written by Martin Krynický, a secondary grammar schoolteacher who placed his electronic teaching texts on the website http://www.realisticky.cz. For the sake of brevity, we will refer to it as a textbook.

${ }^{5}$ Czech secondary school textbooks are not usually accompanied by a teacher's books.
} 
Fourth, we analysed the visual representations present in the textbooks. Each graphical representation found was categorised according to the classification presented in Section 3.2. Any opportunity for a pupil's production of a visual representation was noted. The results for each textbook were put together and compared. All percentages in the tables below are rounded to one decimal place.

\section{Results}

First, we present some descriptive results which will be followed by the results pertinent to each of the research questions. Finally, we present the comparison of content of two editions of one textbook.

According to Table 3, between $2.5 \%$ and $3.7 \%$ of the number of pages in the entire textbook series are devoted to combinatorics. It is noteworthy that there are no significant differences even though each series has a different format. The authors appear to place similar emphasis on combinatorics within the other secondary school topics.

Tab. 3: The number of pages and the share devoted to combinatorics within the whole series

\begin{tabular}{cccc}
\hline Code & $\begin{array}{c}\text { Number of pages } \\
\text { in the whole series }\end{array}$ & $\begin{array}{c}\text { Number of pages } \\
\text { devoted to combinatorics }\end{array}$ & Percentage share \\
\hline $\mathrm{D}$ & 1181 & 29 & $2.5 \%$ \\
\hline $\mathrm{F}$ & 1214 & 38 & $3.1 \%$ \\
\hline $\mathrm{G}$ & 1982 & 73 & $3.7 \%$ \\
\hline $\mathrm{K}$ & $593^{*}$ & 19 & $3.2 \%$ \\
\hline $\mathrm{P}$ & $\begin{array}{c}\text { cannot be } \\
\text { determined** }\end{array}$ & 38 & $\begin{array}{c}\text { cannot be } \\
\text { determined }\end{array}$ \\
\hline
\end{tabular}

*For this textbook, the number of lessons is calculated, not the number of pages, as the textbook comprises individual files, each numbered from page 1.

**At the time of analysis, only five textbooks out of nine had been published.

Table 4 presents the frequency of problems included in the chapters on combinatorics. The majority of problems are formulated in text, that is, they include some context (often a real-world one) and call for combinatorial calculations. The rest of the problems concern numerical and algebraic calculations.

Tab. 4: Share of word problems among all the problems in the chapter on combinatorics

\begin{tabular}{cccc}
\hline Code & $\begin{array}{c}\text { Number of } \\
\text { all problems }\end{array}$ & $\begin{array}{c}\text { Number of } \\
\text { word problems }\end{array}$ & $\begin{array}{c}\text { Percentage of word } \\
\text { problems among all }\end{array}$ \\
\hline $\mathrm{D}$ & 60 & 31 & $51.7 \%$ \\
\hline $\mathrm{F}$ & 81 & 46 & $56.8 \%$ \\
\hline $\mathrm{G}$ & 149 & 107 & $71.8 \%$ \\
\hline $\mathrm{K}$ & 182 & 118 & $64.8 \%$ \\
\hline $\mathrm{P}$ & 119 & 89 & $74.8 \%$ \\
\hline
\end{tabular}

\subsection{Content presentation and the theory of generic models}

Table 5 to Table 7 present results pertinent to the alignment between how the textbooks we analysed present concepts and procedures and the theory of concept development (TGM). The following indicators were included: the type of motivation, the number of IMs and non-models (the presence of the mathematics problems presented before the symbolic representation of abstract knowledge, that is, the definition, theorem or an algebraic formula, usually highlighted by a box), and prompts for search for the IM identity (as prompts to generalise IMs into a GM).

Tab. 5: The introduction of combinatorial rules of sum and product

\begin{tabular}{llccc}
\hline Code & Motivation & $\begin{array}{c}\text { Number } \\
\text { of IMs }\end{array}$ & $\begin{array}{c}\text { Number of } \\
\text { non-models }\end{array}$ & $\begin{array}{c}\text { Prompt to find } \\
\text { IM identity }\end{array}$ \\
\hline $\mathrm{D}$ & tasks, motivational text, history, and applications & 2 & 1 & no \\
\hline $\mathrm{F}$ & $\begin{array}{l}\text { real-life application, figures, games, attractive context of } \\
\text { problems }\end{array}$ & 0 & 0 & no \\
\hline $\mathrm{G}$ & history and applications & 1 & 0 & no \\
\hline $\mathrm{K}$ & attractive context of problems & 6 & 0 & yes \\
\hline $\mathrm{P}$ & history and applications & 2 & 0 & no \\
\hline
\end{tabular}


Tab. 6: The introduction of the concept of $k$-permutations and their number

\begin{tabular}{llccc}
\hline Code & Motivation & $\begin{array}{c}\text { Number } \\
\text { of IMs }\end{array}$ & $\begin{array}{c}\text { Number of } \\
\text { non-models }\end{array}$ & $\begin{array}{c}\text { Prompt to find } \\
\text { IM identity }\end{array}$ \\
\hline $\mathrm{D}$ & motivational text, images, and applications & 4 & 0 & no \\
\hline $\mathrm{F}$ & real-life application, figures, and game & 3 & 0 & no \\
\hline $\mathrm{G}$ & real problem & 0 & 0 & no \\
\hline $\mathrm{K}$ & attractive context of problems & 9 & 0 & yes \\
\hline $\mathrm{P}$ & None & 2 & 0 & no \\
\hline
\end{tabular}

Tab. 7: The introduction of the concept of combinations

\begin{tabular}{llcccc}
\hline Code & Motivation & $\begin{array}{c}\text { Number } \\
\text { of IMs }\end{array}$ & $\begin{array}{c}\text { Number of } \\
\text { non-models }\end{array}$ & $\begin{array}{c}\text { Prompt to find } \\
\text { IM identity }\end{array}$ & $\begin{array}{c}\text { Pascal's } \\
\text { triangle }\end{array}$ \\
\hline $\mathrm{D}$ & motivational text, figures, and game & 1 & 0 & no & yes \\
\hline $\mathrm{F}$ & attractions, figures, real problems, and the game & 1 & 0 & no & no \\
\hline $\mathrm{G}$ & real problem & 1 & 0 & no & yes \\
\hline $\mathrm{K}$ & attractive context of problems & 5 & 0 & yes & yes \\
\hline $\mathrm{P}$ & None & 1 & 0 & no & yes \\
\hline
\end{tabular}

Regarding motivational elements, textbooks $\mathrm{F}$ and $\mathrm{D}$ contain the most variety in the motivational techniques they employed. Textbook K exclusively motivates for combinatorics using word problems with an attractive context; an example is in Fig. 5 below. It seems that when writing the text, the author had in mind specific classes he had taught, as the problems are often set within the context of a secondary class and events pertinent to secondary school life. Textbooks $\mathrm{G}$ and $\mathrm{P}$ motivate the reader through historical notes or real-life problems (an example is in Fig. 3). However, in textbook P, no motivation is included for the concepts and procedures.

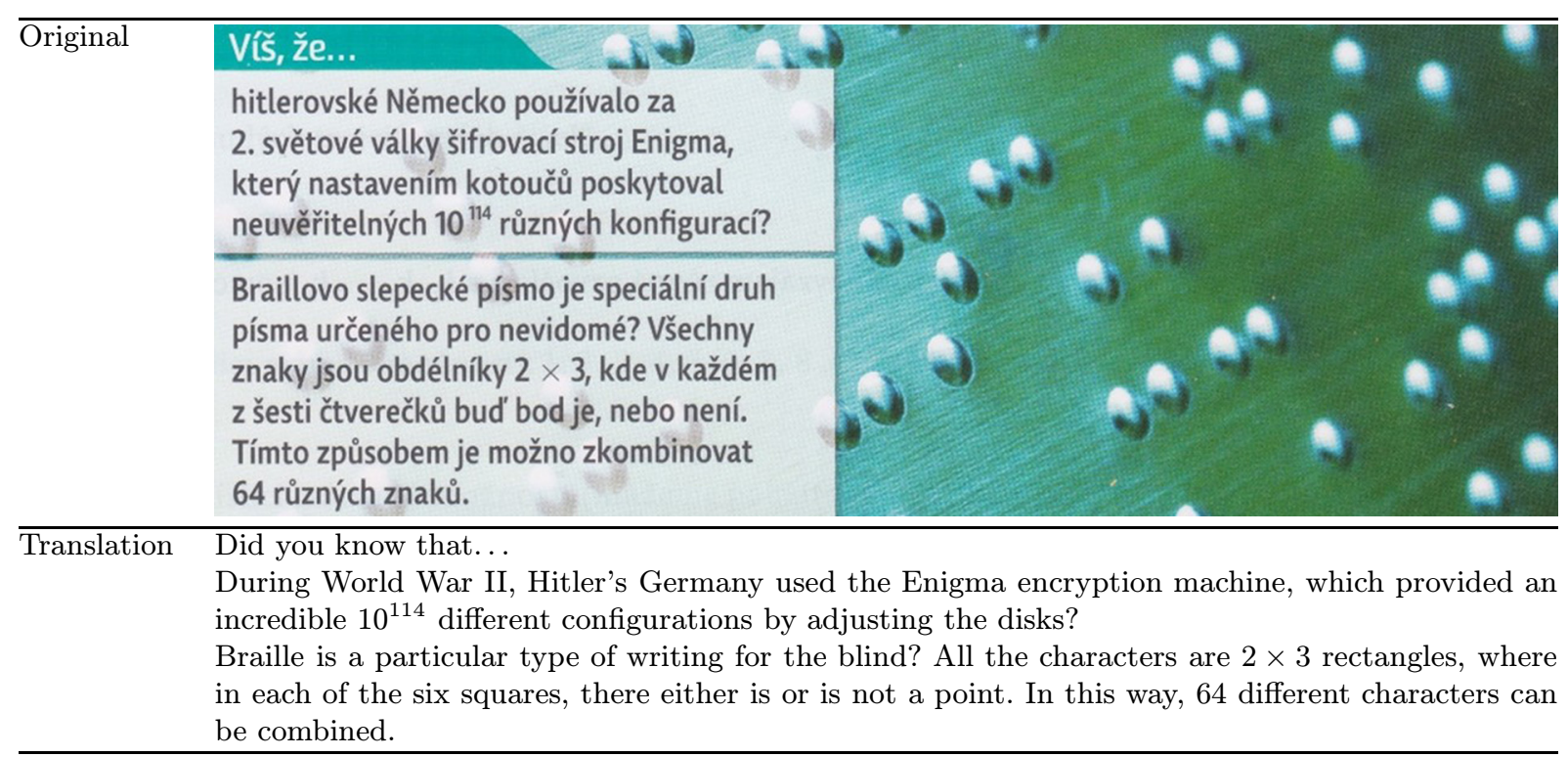

Fig. 3: Illustration of motivation by a real-life application in textbook F (Tlustý, 2020, p. 10)

We identified only one non-model for all the concepts and procedures under our scrutiny. After introducing the rule of sum, the authors explicitly warn that this rule cannot be used in some cases (Fig. 4). It can function as a prevention of over-generalisation.

The creation of GM is a crucial stage in concept development (Hejný, 2012). The number and nature of IMs are an important indicator of the textbook's opportunities for this creation. Table 8 compares the number of isolated models for the concepts studied and the procedures used in the textbooks. In terms of the absolute number of IMs, the textbooks are of three types: I. no or one IM, II. two or three IMs, III. more than three IMs. From Table 8, it is evident that textbook G belongs to type I in all aspects, textbooks $\mathrm{P}$ and $\mathrm{F}$ fall into types $\mathrm{I}$ and $\mathrm{II}$, textbook $\mathrm{D}$ falls into all types, and textbook $\mathrm{K}$ is the only type III textbook. 


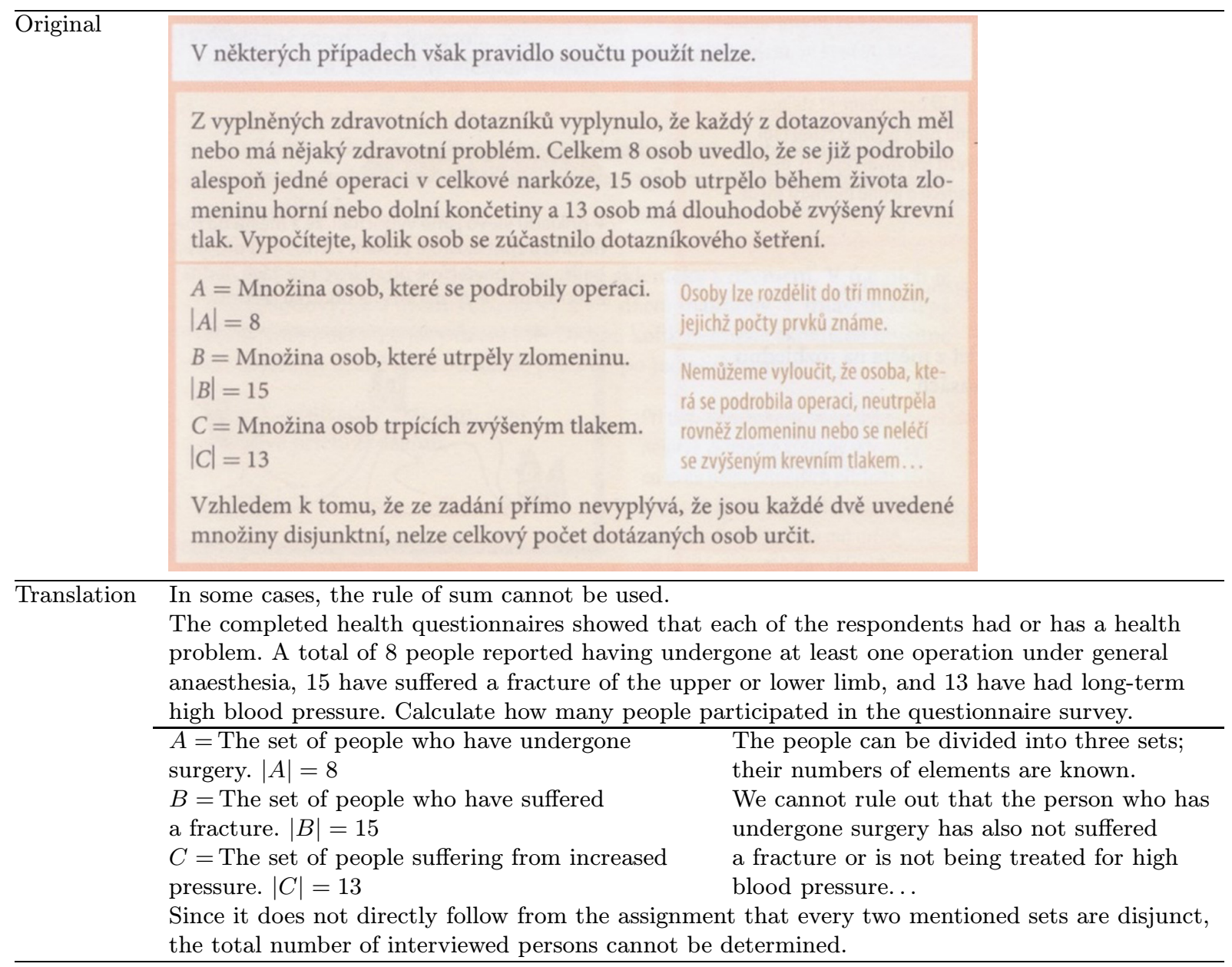

Fig. 4: Illustration of a non-model from textbook D (Horenský et al., 2015, p. 7)

Tab. 8: The number of IMs before the introduction of the symbolic representation

\begin{tabular}{ccccr}
\hline Code & Combinatorial rules & $k$-permutations & Combinations & Total \\
\hline $\mathrm{D}$ & 2 & 4 & 1 & 7 \\
\hline $\mathrm{F}$ & 0 & 3 & 1 & 4 \\
\hline $\mathrm{G}$ & 1 & 0 & 1 & 2 \\
\hline $\mathrm{K}$ & 6 & 9 & 5 & 20 \\
\hline $\mathrm{P}$ & 2 & 2 & 1 & 5 \\
\hline Total & 11 & 18 & 9 & - \\
\hline
\end{tabular}

Another important indicator of the textbook's opportunities for creating a GM consists of explicit prompts to look for the problems' common structure. Similarly to the presence of non-models, we only found such prompts in textbook K. An example is in Fig. 5.

\begin{tabular}{|c|c|c|}
\hline \multirow[t]{4}{*}{ Original } & Př. 1: & $\begin{array}{l}\text { Sportovního turnaje se účastni } 6 \text { týmů. Kolika způsoby mohou tyto týmy obsadit } \\
\text { medailová mista v konečném umístěni? }\end{array}$ \\
\hline & Př. 2: & $\begin{array}{l}\text { Na maturitním plese se } 10 \text { hlavních cen v tombole losuje z } 250 \text { listků. Kolika } \\
\text { způsoby může toto losování dopadnout? }\end{array}$ \\
\hline & Př. 3: & $\begin{array}{l}\text { Na zkoušeni jsou připraveny dvě otázky (otázky nejsou stejné) a studenti jsou } \\
\text { losováni náhodně. Kolika zpủsoby múže losováni dopadnout, pokud je ve třidě } 31 \\
\text { studentů? }\end{array}$ \\
\hline & Př. 4: & Najdi společné rysy všech předchozích př́kladủ. \\
\hline \multirow[t]{4}{*}{ Translation } & Pr. 1: & $\begin{array}{l}\text { Six teams take part in a sports tournament. How many ways can these teams take } \\
\text { medals in the final standings? }\end{array}$ \\
\hline & Pr. 2: & $\begin{array}{l}\text { At the prom, the } 10 \text { main prizes in the tombola are drawn from } 250 \text { tickets. How many } \\
\text { ways can this draw turn out? }\end{array}$ \\
\hline & Pr. 3: & $\begin{array}{l}\text { Two questions are prepared for the exam (they are not the same), and students are } \\
\text { drawn randomly. How many ways can a draw turn out if there are } 31 \text { students in a class? }\end{array}$ \\
\hline & Pr. 4: & Find the common features of all the previous problems. \\
\hline
\end{tabular}

Fig. 5: Illustration of the prompt to search for IM identity from textbook K (Krynický, 2021a, p. 1) 
Finally, Fig. 6 presents an example of the symbolic representation of abstract knowledge.

\begin{tabular}{ll}
\hline Original & Translation \\
\hline zapamatujeme si & Let us remember \\
Pro všechna celá $n, k$, kde $0 \leq k \leq n$, je: $C(n, k)=\left(\begin{array}{l}n \\
k\end{array}\right)=\frac{n !}{k ! \cdot(n-k) !}$ & $\begin{array}{l}\text { For all integers } n, k, 0 \leq k \leq n, \text { it is: } \\
C(n, k)=\left(\begin{array}{l}n \\
k\end{array}\right)=\frac{n !}{k ! \cdot(n-k) !}\end{array}$ \\
\hline
\end{tabular}

Fig. 6: Symbolic representation of abstract knowledge from textbook F (Tlustý, 2020, p. 22)

\subsection{Visual representations}

Table 9 shows the number of visual representations in each textbook and the number of prompts to make such representations. Textbook D contains the most visual representations, and textbook $\mathrm{K}$ the least. However, the latter contains many more prompts to create representations, compared to the other textbooks, where these prompts are exceptional. Tab. 10 presents the categories of visual representations.

Tab. 9: The number of visual representations in the textbook and prompts for their creation

\begin{tabular}{lrrrrr}
\hline Code & D & F & G & K & P \\
\hline Number of representations & 32 & 17 & 29 & 10 & 17 \\
\hline Number of calls for representations & 1 & 1 & 1 & 10 & 2 \\
\hline
\end{tabular}

Tab. 10: Categories of visual representations in the textbooks and prompts for their creation

\begin{tabular}{|c|c|c|c|c|c|c|c|c|c|}
\hline Code & Category & Trees & Charts & $\begin{array}{c}\text { Venn } \\
\text { diagrams }\end{array}$ & $\begin{array}{c}\text { Systematic } \\
\text { lists }\end{array}$ & Tables & Figures & $\begin{array}{l}\text { Other visual } \\
\text { representations }\end{array}$ & $\overline{\text { Total }}$ \\
\hline \multirow[t]{2}{*}{$\mathrm{D}$} & frequency & 2 & 1 & 1 & 6 & 0 & 8 & 14 & 32 \\
\hline & prompts & $\overline{0}$ & $\overline{0}$ & $\overline{0}$ & 1 & 0 & 0 & 0 & 1 \\
\hline \multirow[t]{2}{*}{$\mathrm{F}$} & frequency & 1 & 2 & 0 & 8 & 0 & 1 & 5 & 17 \\
\hline & prompts & 0 & 0 & 0 & 1 & 0 & 0 & 0 & 1 \\
\hline \multirow[t]{2}{*}{$\bar{G}$} & frequency & 0 & 2 & 0 & 11 & 2 & 6 & 8 & 29 \\
\hline & prompts & 0 & 0 & 0 & 0 & 1 & 0 & 0 & 1 \\
\hline \multirow[t]{2}{*}{$\bar{K}$} & frequency & 0 & 1 & 0 & 3 & 0 & 3 & 3 & 10 \\
\hline & prompts & 0 & 0 & 0 & 4 & 0 & 0 & 6 & 10 \\
\hline \multirow[t]{3}{*}{$\bar{P}$} & frequency & 0 & 1 & 1 & 10 & 0 & 2 & 3 & 17 \\
\hline & prompts & 0 & 0 & 0 & 1 & 1 & 0 & 0 & 2 \\
\hline & Total & 3 & 7 & 2 & 46 & 4 & 15 & 39 & - \\
\hline
\end{tabular}

The most frequently used representation in textbooks $\mathrm{G}$ and $\mathrm{P}$ (Tab. 10) is a mathematical one consisting of enumerating elements from the set of letters $\{a, b, c, \ldots\}$. In textbook $\mathrm{F}$, most representations are also in the form of a statement of results, although in the form of a graphical representation with arrows, circles, card images, etc. The most common category of representation of spatial reorganisation in textbook $\mathrm{D}$ is a positional diagram.

For all the textbooks, we can order the categories of representations in terms of frequency as follows: systematic lists (46), other visual representations (39), figures (15), charts (7), tables (4), trees (3) and Venn diagrams (2).

The textbooks also differ in their graphical design, which directly impacts visual representation. Textbooks $\mathrm{G}$ and $\mathrm{K}$ hardly ever use colours, and thus schemes and visual representations are less illustrative (Fig. 7, left). On the other hand, textbooks D and F are the most colourful, which might help pupils to make better sense of the solution depicted (Fig. 7, right).
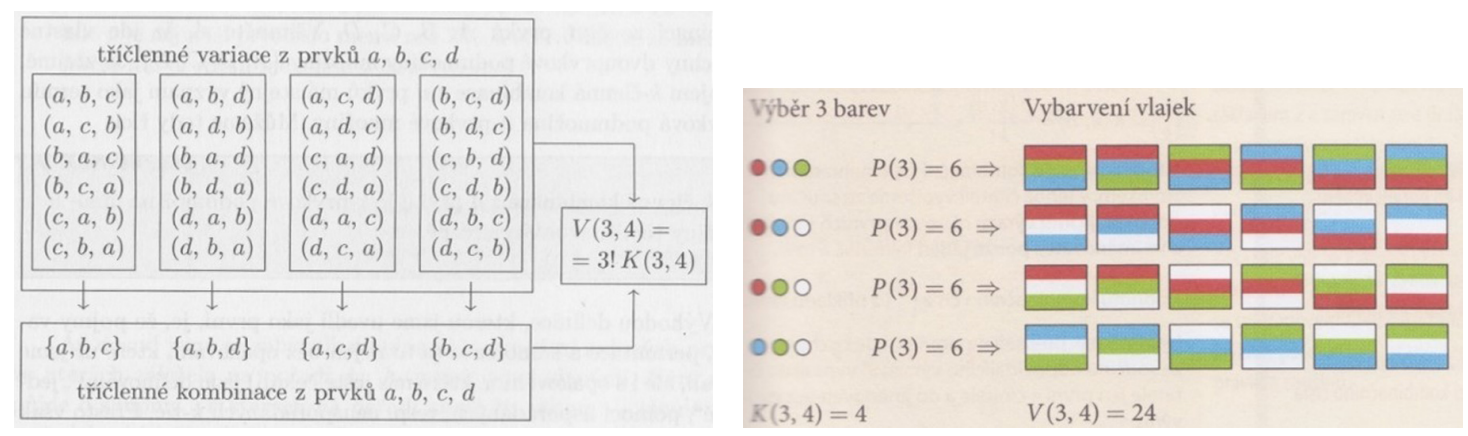

Fig. 7: Systematic lists in black and white, textbook G (Calda \& Dupač, 2012, p. 13), in colour, textbook D (Horenský et al., 2015, p. 25) 
Pascal's triangle is a particular type of visual representation. It is present in all the textbooks except F (Tab. 11).

Tab. 11: Number of occurrences of the Pascal triangle scheme in textbooks

\begin{tabular}{lccccc}
\hline Code & D & F & G & K & P \\
\hline Number of occurrences of Pascal's triangle & 5 & 0 & 4 & 1 & 2 \\
\hline
\end{tabular}

All the textbooks introduce Pascal's triangle in several steps. First, some properties of combination numbers are summed up, including Pascal's identity $\left(^{*}\right)$, which is called the property of combination numbers and is always presented symbolically. The above properties are then used to solve some problems, and it is noted that a specific diagram can be made to depict them (see Fig. 8). The conception of Pascal's triangle in textbook G ("These properties of combination numbers can be illustrated in the following diagram, called Pascal's triangle." Calda \& Dupač, 2012, p. 61) is similar to textbook K's ("Thanks to the relations for combination numbers, we can construct an interesting pattern... Because it is composed entirely of combination numbers, it is possible to demonstrate the relations that apply to them." Krynický, 2021 b, pp. 3, 4). The validity of the properties of combination numbers is only illustrated or demonstrated in this scheme. Following this scheme, some problems related to Pascal's triangle and dealing with the enumeration of a row of Pascal's triangle, or the sum of several combination numbers are included. Finally, the textbooks relate Pascal's triangle to binomial coefficients.

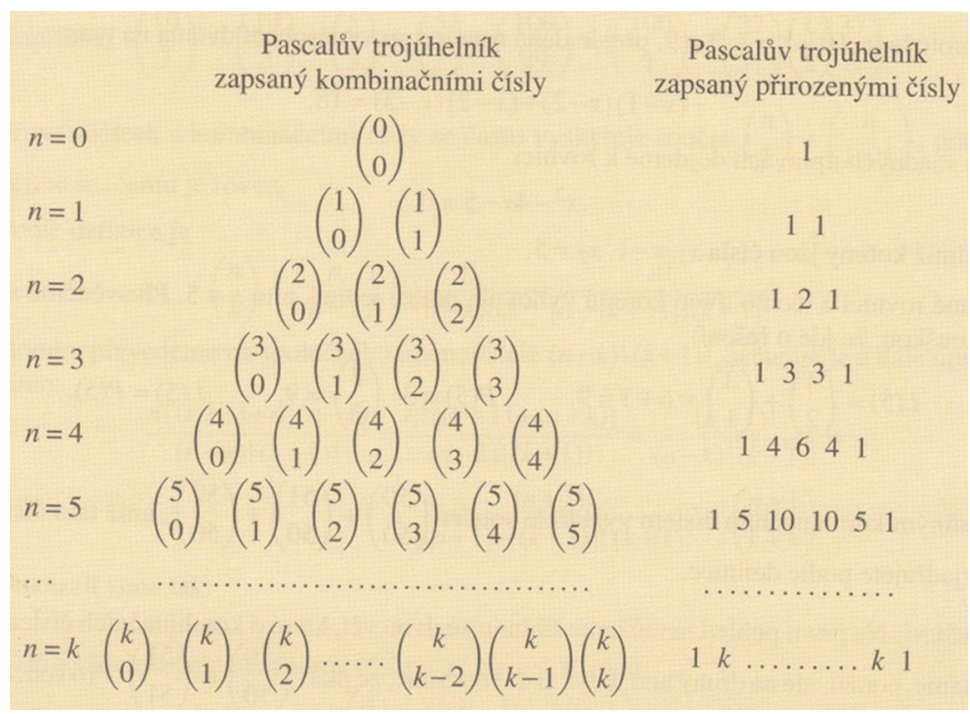

Fig. 8: Pascal's triangles with combination numbers and natural numbers from textbook P (Robová et al., 2013, p. 82)

An exception to the above is textbook D, which, unlike the other textbooks, contains many challenges to find different contexts in Pascal's triangle, e.g., fractals (see Fig. 9).

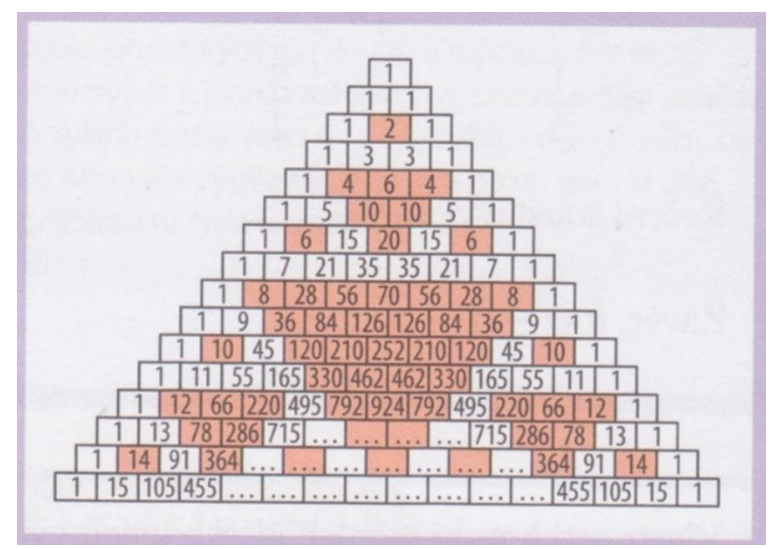

Fig. 9: Illustration of fractals included in Pascal's triangle from textbook D (Horeský et al., 2015, p. 32) 


\subsection{Two editions of one textbook}

The first edition of textbook G was published in 1993, while the latest (fifth) is from 2012. The authors remained the same. We analysed both editions to see what changes had been made in the editions nearly 20 years apart, and found that they were almost the same. Only minor differences were found in the solved problems and the explanatory text. Seven new problems were added, but they deal exclusively with algebraic modifications of expressions, which contain combinatorial concepts including factorial or combination numbers. This type of solved problems was almost absent from the first edition, although unsolved problems with these concepts were included. These differences in the explanatory text are also present in the notes. In the fifth edition, two notes were added, which provide the reader with instructions on how to a) deal with combination number calculations, b) why the problem of placing identical objects in compartments can be likened to combinations with repetition.

\section{Discussion}

All the textbooks we analysed, except for textbook F, in which Pascal's triangle and the binomial theorem are absent, comply with the Czech national curricular material. They fulfil the outputs of the FEP and in many ways exceed them (textbooks G, K, D).

Recall that we conducted our analysis from the position that the presentation of combinatorial concepts and procedures complying with the theory of concept development in mathematics will enhance the possibility that teaching with such a textbook will lead to pupils learning the content with understanding.

\subsection{The presentation of content in terms of concept development in mathematics}

There is very little difference in how the textbooks approach the combinatorial rules (of sum and product) and the combinatorial categories ( $k$-permutations, combinations) in terms of the prominence they are given. They are presented in the same way and summarised in the same graphical way (enclosed in boxes as in Fig. 6).

As for the first stage of learning, motivation, we found that while all the textbooks contained some motivational elements, they differed in their diversity. Some of the textbooks provide teachers with more support in motivating pupils towards this subject matter than the others.

Studies show that pupils have difficulty in identifying related problem structures (e.g., English, 2005), and thus their "ability to transfer their learning to new combinatorial situations is limited" (p. 135). To transfer their learning to new situations, pupils should be presented with enough isolated models to create a GM before being introduced to an abstract definition, theorem or formula. Such recommendations are common in combinatorics. For example, Lockwood and Gibson (2016) highlight the importance of the systematic list strategy and recommend that pupils are given enough problems that are solvable with this strategy and are led to look for the organisational principle before being introduced to the combinatorial formulas. Uptegrove (2015) describes how pupils can develop their combinatorial thinking and reach the stage of abstract knowledge by solving concrete combinatorial problems and considering their isomorphism.

Given the above, we focused on the number of IMs, non-models and prompts to generalise in the textbooks. The results for the number of IMs varied across both textbooks and concepts and procedures. It is natural, for example, that if the $k$-permutations are introduced before combinations, the number of IMs is large for the former. However, the textbooks differed vastly in terms of the total number of IMs for combinatorial rules, $k$-permutations, and combinations. Textbook $\mathrm{G}$, with only $2 \mathrm{IMs}$, and textbook $\mathrm{K}$, with $20 \mathrm{IMs}$, are on opposite poles. The situation is similar in the presence of non-models and prompts for generalisation. Both were found in textbook $\mathrm{K}$ and absent in the other textbooks (except for one non-model in textbook D).

The absence of non-models might have a serious consequence of over-generalisation, to which pupils might be prone if introduced to models only. Provided that the concepts of $k$-permutations and combinations are grounded in the isomorphism of concrete situations (English, 2005; Hejný, 2014; Kapur, 1970), it seems worrying that except for textbook $\mathrm{K}$, the textbooks do not capitalise on this isomorphism. Of course, the other textbooks state directly or implicitly that some problems have the structure of, for example, combinations, but do not specifically ask pupils to look for this common structure. Such a prompt would foster independent thinking in combinatorics (English, 2005). The prompts for such a generalisation in the textbook might help the teacher (or pupils) see its importance. Except for textbook K, the other textbooks emphasise the end product (mathematics procedures and concepts presented via rules and definitions) at the expense of the process of reaching this end product. The teachers are expected to make the didactic reconstruction of these procedures and concepts themselves. 


\subsection{Visual representations}

The importance of visual representation for solving combinatorial problems is generally acknowledged (e.g., English, 2005; Hejný et al., 1990; Lockwood \& Gibson, 2016; Uptegrove, 2015; Vondrová, 2019; Zahner \& Corter, 2010) as it provides support for the solution, visualises an organisational principle upon which this solution rests, or helps to communicate the solving strategy or the result of the solution. We focused on the presence and diversity of visual representations and on prompts for pupils to create such representations in the textbooks. Such prompts may be a way to support pupils' metacognition.

The diversity of visual representations in the textbooks varies from textbook $\mathrm{D}$ (the most diverse) to $\mathrm{K}$ (the least). While one textbook $(\mathrm{K})$ includes several prompts for pupils to create their representations, such prompts are rare in the other textbooks. Neither textbook includes any suggestion to make representations in the form of a tree, chart, Venn diagram, or figure. It seems a paradox to us that the tree and table are the least used representations in the textbooks, although they are the recommended tools through which data can be clarified and visualised (e.g., Lockwood \& Gibson, 2016).

It also transpired that some representations which appear to be natural and are known from the literature (Zahner \& Corter, 2010) do not appear in the analysed textbooks at all, namely, a contingency table or problems solvable on grid paper. In the Czech context, such representations are widely used in a series of primary school textbooks (e.g., Hejný \& S̆alom, 2017) in which the propaedeutics of combinatorics is carefully developed. Fig. 10 gives an example.

\begin{tabular}{ll}
\hline Original & Kolik rovnoramenných trojúhelníkủ $\mathrm{ABC}$ lze najít na tomto čtverci, když body $\mathrm{B}$ a $\mathrm{C}$ jsou dva mřruzové body na hranici čtverce (bod $\mathrm{B}$ ani \\
bod $C$ neleži uvnitř čtverce).
\end{tabular}

Fig. 10: Illustration of visual representation on a grid paper (Hejný et al., 2017, p. 39)

Pascal's triangle is a specific type of visual representation. The four textbooks that introduce Pascal's triangle also include Pascal's identity $(*)$. However, Pascal's triangle is only presented to illustrate or demonstrate the previously introduced properties of combination numbers. Moreover, contrary to what is required by TGM, the potential IMs of this equality are always provided only after its symbolic presentation (and in some cases, after its proof). Thus, these instances cannot be considered IMs but rather concrete examples of the symbolic form of Pascal's identity.

Uptegrove's (2015) longitudinal study might offer inspiration for an opposite approach to the introduction of Pascal's triangle and Pascal's identity $(*)$. The pupils in the study discovered an abstract piece of knowledge $(*)$ based on the study of two combinatorial problems, the discovery of isomorphism and investigating the structure of Pascal's triangle. Thus, the introduction of Pascal's triangle can come before Pascal's identity $(*)$.

\section{Conclusions, limitations, and further work}

Textbooks are an essential part of mathematics lessons and their content might provide teachers with important support when designing such lessons that have good potential to lead to learning the content with understanding. This study found that none of the five Czech textbooks on combinatorics we analysed can be seen as fully supportive. Textbooks K and D differ the most in terms of teacher support. A teacher using the former will receive ample support in teaching in compliance with TGM, that is, instruction focused on generalising and abstracting as the essential processes in mathematics (Vinner, 2014). A teacher using the latter might be directed towards using more formal teaching methods (from the definition to its examples). Note that we are not claiming that using a specific textbook will necessarily lead to just one way of teaching (and pupils' learning). Instead, we refer to how the textbook may or may not support the teacher in their quest to teach in a certain way.

Our analysis against the theoretical background of TGM helped to reveal insufficiencies in the presentation of content in the textbooks that would otherwise remain hidden, the most important of which $\mathrm{s}$ are the insufficient motivation of individual concepts, the low number of IMs, or the absence of non-models. With one exception, the textbooks do not lead pupils to search for isomorphisms of IMs or encourage them to generalise. Let us emphasise again that these processes are essential for the creation of sound abstract knowledge (Hejný, 2012; Vinner, 2014). We also identified a low number and variety of visual 
representations, and very few prompts to visualise in the textbooks. This can impede the quality of teaching, as the textbooks do not alert the teacher to the fact that visual representations are a crucial means for solving combinatorial problems (Lockwood \& Gibson, 2016; Salavatinejad et al., 2021; Uptegrove, 2015).

The results summarised above may provide a starting point for other investigations. For example, we could focus on how the analysed textbooks are actually used in the lessons by both teachers and pupils. Is our assumption that the textbook influences how teachers design their instruction valid? Are teachers aware of the fact that the textbook, for example, does not sufficiently promote visual representations and do they lead their pupils to such representations? Such matters warrant more research.

Our results might assist the authors of teaching texts on combinatorics. Finally, the methodology used in the study (namely, the use of TGM) could help researchers wishing to investigate textbooks from other topics.

The results of our study have limitations. The first lies in the selection of textbooks. We could augment the study by analysing textbooks on combinatorics from abroad and by textbooks for the primary school, which should ideally include the propaedeutics of combinatorics (see, e.g., Hejný \& Šalom, 2017).

The division of visual representations into categories represents another limitation, as other categorisations could be used (Corter \& Zahner, 2007) or more specific subcategories elaborated. However, considering that the number of visual representations was relatively low, we doubt that this would bring noteworthy results.

We have used one specific theory of concept development to augment descriptive results. It might be worthwhile to complement our analysis with a different theory as a background. We could also focus on some more specific suggestions for teaching combinatorics (such as the problem-posing opportunities suggested by English, 2005) and whether and how they are projected in the textbooks.

\section{Acknowledgment}

This work was supported by the PROGRES Q17 project, 'Teacher Preparation and the Teaching Profession in the Context of Science and Research'. We thank Nad’a Vondrová for many critical comments and suggestions, which hopefully contributed to the quality of the article.

\section{References}

Apple, M. (1986). Teachers and texts: A political economy of class and gender relations in education. Routledge \& Kegan Paul.

Arcavi, A. (2003). The role of visual representations in the learning of mathematics. Educational Studies in Mathematics, 52(3), 215-241. https://doi.org/10.1023/A:1024312321077

Batanero, C., Navarro-Pelayo, V., \& Godino, J. D. (1997). Effect of the implicit combinatorial model on combinatorial reasoning in secondary school pupils. Educational Studies in Mathematics, 32(2), 181-199.

Corter, J. E., \& Zahner, D. C. (2007). Use of external visual representations in probability problem solving. Statistics Education Research Journal, 6(1), 22-50.

English, L. D. (2005). Combinatorics and the development of children's combinatorial reasoning. In G. Jones. (Ed.) Exploring probability in school (pp. 121-141). Springer. https://doi.org/10.1007/0-387-24530-8_6

Fan, L. (2013). Textbook research as scientific research: towards a common ground on issues and methods of research on mathematics textbooks. ZDM, 45(5), 765-777. https://doi.org/10.1007/s11858-013-0530-6

Fan, L., Zhu, Y., \& Miao, Z. (2013). Textbook research in mathematics education: development status and directions. ZDM, 45(5), 633-646. https://doi.org/10.1007/s11858-013-0539-x

Fischbein, E., \& Gazit, A. (1988). The combinatorial solving capacity in children and adolescents. Zentralblatt für Didaktik der Mathematik, 5, 193-198.

Grimaldi, R.P. (2003). Discrete and combinatorial mathematics: An applied introduction. Addison-Wesley.

Hejný, M. (2004). Mechanismus poznávacího procesu [Mechanism of the cognitive process]. In M. Hejný, J. Novotná, \& N. Stehlíková (Eds.), Dvacet pět kapitol z didaktiky matematiky (s. 23-42). PedF UK v Praze.

Hejný, M. (2012). Exploring the cognitive dimension of teaching mathematics through scheme-oriented approach to education. Orbis scholae, 6(2), 41-55. https://doi.org/10.14712/23363177.2015.39

Hejný, M. (2014). Vyučování matematice orientované na budování schémat: Aritmetika 1. stupně [Teaching schematic oriented mathematics: Grade 1 arithmetic]. Univerzita Karlova, Pedagogická fakulta. 
Hejný, M., Benešová, M., Bereková, H., Bero, P., Hrdina, L'., Repáš, V., \& Vantuch, J. (1990). Teória vyučovania matematiky 2 [Theory of teaching mathematics 2]. SPN.

Hejný, M., Eichlerová, K., \& Salom, P. (2017). Matematika B: Pracovní sešit pro 2. stupeň ZŚ a víceletá gymnázia (první vydání) [Mathematics B: Workbook for the 2nd level of elementary school and multiyear grammar school (first edition)]. H-mat.

Hejný, M., \& Kuřina, F. (2009). Dítě, škola a matematika. Konstruktivistické př́stupy k vyučováni [Child, school and math. Constructivist approaches to teaching.]. Portál.

Hejný, M., \& Salom, P. (2017). Matematika E: Učebnice pro 2. stupeř ZŚ a víceletá gymnázia (první vydání) [Mathematics E: Textbook for the 2nd grade of elementary school and multiyear grammar school (first edition)]. H-mat.

Kapur, J. N. (1970). Combinatorial analysis and school mathematics. Educational Studies in Mathematics, 3(1), $111-127$.

Lockwood, E., \& Gibson, B. R. (2016). Combinatorial tasks and outcome listing: Examining productive listing among undergraduate students. Educational Studies in Mathematics, 91(2), 247-270.

https://doi.org/10.1007/s10649-015-9664-5

Mason, J., \& Johnston-Wilder, S. (2005). Fundamental constructs in mathematics education. RoutledgeFalmer.

MŠMT [Ministry of Education, Youth and Sports], (2017). Rámcový vzdělávací program pro základní vzdělávání [Framework Education Programme for Basic Education]. Praha. http://www.msmt.cz/file/43792/

MŠMT [Ministry of Education, Youth and Sports], (2016). Rámcový vzdělávací program pro gymnázia [Framework Education Programme for Secondary General Education]. [online] Praha. http://www.nuv.cz/t/rvp-pro-gymnazia

Salavatinejad, N., Alamolhodaei, H., \& Radmehr, F. (2021). Toward a model for students' combinatorial thinking. The Journal of Mathematical Behavior, 61, 100823. https://doi.org/10.1016/j.jmathb.2020.100823

Speiser, B., Walter, C., \& Sullivan, C. (2007). From test cases to special cases: Four undergraduates unpack a formula for combinations. The Journal of Mathematical Behavior, 26(1), 11-26. https://doi.org/10.1016/j.jmathb.2007.03.003

Stofflett, R. T., \& Baker, D. R. (2016). The effects of training in combinatorial reasoning and propositional logic on formal reasoning ability in junior high school students. Research in Middle Level Education, 16(1), 159-177. https://doi.org/10.1080/10825541.1992.11670007

Tarr, J.E., Chávez, O., Reys, R.E., \& Reys, B. J. (2006). From the written to the enacted curricula: The intermediary role of middle school mathematics teachers in shaping students' opportunity to learn. School Science and Mathematics, 106(4), 191-201. https://doi-org.ezproxy.is.cuni.cz/10.1111/j.1949-8594.2006.tb18075.x

Uptegrove, E. B. (2015). Shared communication in building mathematical ideas: A longitudinal study. The Journal of Mathematical Behavior, 40, 106-130. https://doi.org/10.1016/j.jmathb.2015.02.001

Van Steenbrugge, H., Valcke, M., \& Desoete, A. (2013). Teachers' views of mathematics textbook series in Flanders: Does it (not) matter which mathematics textbook series schools choose? Journal of Curriculum Studies, 45(3), 322-353. https://doi.org/10.1080/00220272.2012.713995

Vinner, S. (2014). Concept development in mathematics education. In S. Lerman (Ed.), Encyclopedia of Mathematics Education (pp. 91-95). Springer. https://doi.org/10.1007/978-94-007-4978-8_147

Vondrová, N. (2019). Didaktika matematiky jako nástroj zvládání kritických míst v matematice [Didactics of mathematics as a tool for managing critical places in mathematics]. Univerzita Karlova, Pedagogická fakulta.

Zahner, D., \& Corter, J. E. (2010). The process of probability problem solving: Use of external visual representations. Mathematical Thinking and Learning, 12(2), 177-204.

https://doi.org/10.1080/10986061003654240

\section{Textbooks}

Calda, E., \& Dupač, V. (1993). Matematika pro gymnázia - Kombinatorika, pravděpodobnost a statistika (první vydání) [Mathematics for grammar schools - Combinatorics, probability and statistics (first edition)]. Prometheus.

Calda, E., \& Dupač, V. (2012). Matematika pro gymnázia: kombinatorika, pravděpodobnost a statistika (dotisk pátého vydání) [Mathematics for grammar schools: Combinatorics, probability and statistics (reprint of the fifth edition)]. Prometheus.

Horenský, R., Janů, I., Květoňová, M., Lukšová, H., \& Vémolová, R. (2015). Matematika pro střední školy 8. díl: Kombinatorika, pravděpodobnost, statistika - Učebnice (první vydání) [Mathematics for secondary schools - part 8: Combinatorics, probability, statistics - Textbook (first edition)]. Didaktis. 
Krynický, M. (2021a). Matematika SS̆.realisticky.cz: Kombinatorika: Variace I (př́klady) [Mathematics SS̆.realisticky.cz: Combinatorics: $k$-permutations I (examples)].

https://www.realisticky.cz/ucebnice/01\%20Matematika\%20S\%C5\%A0/09\%20Kombinatorika, \%20pravd\%C4 \%9Bpodobnost, \%20statistika/01\%20Kombinatorika/04\%20Variace\%20l/p\%C5\%99\%C3\%ADklady.pdf

Krynický, M. (2021b). Matematika SS̆.realisticky.cz: Kombinatorika: Další vlastnosti kombinačních čísel (lekce) [Mathematics SŠ.realisticky.cz: Combinatorics: Other properties of combination numbers (lesson)]. https://www.realisticky.cz/ucebnice/01\%20Matematika\%20S\%C5\%A0/09\%20Kombinatorika, \%20pravd\%C4\% 9Bpodobnost, \%20statistika/01\%20Kombinatorika/17\%20Dal\%C5\%A1\%C3\%AD\%20vlastnosti\%20kombina\%C4 $\% 8$ Dn $\%$ C3\%ADch $\% 20 \%$ C4\%8D\%C3\%ADsel.pdf

Robová, J., Hála, M., \& Calda, E. (2013). Matematika pro střední školy: Komplexní čísla, kombinatorika, pravděpodobnost a statistika (první vydání) [Mathematics for secondary schools: Complex numbers, combinatorics, probability, and statistics (first edition)]. Prometheus.

Tlustý, P. (2020). Matematika s nadhledem od prváku k maturitě: kombinatorika, pravděpodobnost a statistika / 13. díl (první vydání) [Mathematics with an overview from freshman to high school diploma: combinatorics, probability and statistics / part 13 (first edition)]. Fraus. 